\title{
Analysis of Consigment Sales Rating to 2014 Profit In CV. Lam alif Purwakarta
}

\author{
Gusganda Suria Manda ${ }^{(1)}$, Dian Hakip Nurdiansyah ${ }^{(2)}$ \\ Universitas Singaperbangsa Karawang \\ Gusganda.suriamanda@fe.unsika.ac.id \\ dian.hakipnurdiansyah@staff.unsika.ac.id
}

\begin{abstract}
The study was conducted with the background, that assessment consignment sales has a direct influence on the financial position of a company and is also considered important because it will indirectly affect the financial statements include a profit and loss. The purpose of this research is to analyze how the results of the calculation of the gain on sale of consignment sales in retail trade company, how a journal to record transactions consignment sales held separately by physical methods, and how the company's ability to generate profits by selling on consignment at CV.LAM ALIF year 2014. Data collection through literature research method, observation, interviews and secondary data from reports of sales and income. The data analysis was descriptive analysis by compiling and classifying the data obtained, then interpreted after the first consignment sales assessment calculation.Results of the study showed that the assessment of the existing consignment sales in retail trade companies (CV. LAM ALIF) for 2014 is quite good, based on the analysis obtained by the profit generated positive accumulated. Judging from the commissions generated that will affect revenue earnings. The conclusion, that the retail trading companies already applying Alif CV.Lam consignment sales. The larger the greater the sales commissions earned by CV. Alif Lam and vice versa if the low sales commissions earned also low. To that end, the need for an increase in consignment sales especially in the bidding.
\end{abstract}

Keyword : Consigment, sales profit, financial

\section{INTRODUCTION}

A company's success is generally evaluated from its ability to generate profit. Using the profits earned, a company will carry out various activities to increace its active and capital, and to expand and develop its field of business. To achieve the purpose, a company 
focuses its acitivities on sales formats, as the greater the volume of sales, the bigger the profits earned.

CV. LAM ALIF is a franchise company engaged in retail sales, established in 2012. This company claims that consignment sales generate profits without requiring expenses, as the company can earn profit only from selling their products or receiving commission from the owners of the products. The owners will only receive the tagged price of the products, reduced from the percentage agreed to be claimed as profits by CV. LAM ALIF.

Based on the background of the study, the researcher is interested to analyse the case to prove the significance of consignment sales in increasing a company's profit, hence the title of the research "Analysis of consignment sales valuation to profit rate of 2014 at $\mathrm{CV}$. Lam Alif, Purwakarta"

\section{LITERATURE REVIEW}

\section{Definition of Sales}

Sales is one of the activities a company performs to generate income. It will affect the amount of profits received by the company. "Sales is science and art affecting an individual done by a seller to persuade others to buy the goods or services offered". (Basu Swastha, 2005:8). Sales is redirection or transfer of the ownership of a product or a service from a seller to the buyer, along with reward from the receiver of the products or services as reciprocity of the transfer. In selling products of a company, one needs to apply three sales methods including cash sales, credited sales, and consignment sales.

\subsubsection{Consignment Sales}

The transfer from the manufacturer (wholesale) to the dealers (sellers) is not considered as the entire sales procedure as the manufacturer still owns the rights on the products in several agreements. The specific method to market these products is known as consignment. According to the agreement, the consignor (manufacturer) transfers the products to consignee (dealer), which acts as the agent of both consignor and consignee involved in the sales, to first earn profits or expand the market and to second receive the commission out of the deal.

\subsubsection{Record Method of Consignment Sales}

Consignment transaction is recorded separately from the others, so the consignor must make account for "consignment goods" regardless whatever method is used in the process. The delivery of the products is recorded in a "memorandum" if it is not recorded separately from the others. 


\subsubsection{Sales Purpose}

The main purpose of the company is to achieve a certain rate of sales, to generate profits, and escalating the business growth (Basu Swastha, 2005:67).

\subsubsection{Sales Procedure}

The sales procedure depends on the format of business, sales method, and the kind of products or service offered. A transaction of sales starts where the order is received, and ends when the products is handed to the customer. The functions involved in the cycle of sales, according to (Arens et all, 2006:37) include Processing Customer Order, Granting Credit, Shipping Point, Billing Customer and Recording Sales, Processing and Recording Cash Receipt, Processing and Recording Sales Return Allowance, Changing of Uncollectible Account Receivable, and Providing for Bad Debts

\subsection{Definition of credit}

"Credit is a claim to another party regarding funds, products, or service received within a year, or in one cycle of a company's acitivities". (Mulyadi, 2008:87) "Business credit is a balance received by the customer" (Ambarwati, 2010:155)

Credit is a bill incurred to individuals or companies received in cash. (Slamet Sugiri, 2009:43) Credit is a company's claim on funds, products or services to another party as the outcome of previous transaction. (Rudianto, 2009:224)

Based on the aforementioned definitions, it can be concluded that credit/receivable includes a claim to a third party either in the form of cash, products or services. In accounting, the term credit is only used to refer to a claim from a third party which is expected to be received in cash in a normal activity of a company.

\subsection{Profits (income)}

Profits is a reward on an investment. The widely-known definition of profits states that it is the amount of money that can be transferred back to investior without affecting the company's stability, just like in the initial establishment. (Sugiarto, 2012:2.3)

\section{Admittance of Income and Profits}

The term income in accounting is differed by the term earnings. Earnings includes income and profits, with income generated from the company's regular activities such as sales, service production, interests, dividend, royalty, and rent. Profits reflects the other aspects included in earnings and might or might not be generated in the company's regular activity. (IAI, PSAK, 2001:19) 


\section{RESEARCH METHOD}

\section{Overview of Research Object}

The research site is CV. LAM ALIF, located in yang berada Paldalapan Village, Campaka District, Purwakarta. The research started in May 2015. CV. LAM ALIF is one of the franchises of PT. Sumber Alfaria Trijaya, which is a franchise company.

\section{Research Design}

A research is the process of discovering a matter systematically within a fixed longterm period using scientific method and according to applicable terms and conditions. (Nazir, 2011:84)

Research method is the ways used by the researcher in completing the study. (Arikunto, 2013:151)

Quantitative data used as the research data is obtained from the annual invoice of CV.LAM ALIF, containing the names of the products to be sold (Arikunto, 2013:172). The source of data in this research is primary as it is obtained directly from the company's data, information, and documents. Secondary data is also used in the form of additional data collected from literature study or references from experts in the subject of the research, selected using the method of Quotasi, Phrase, Summary. The researcher uses Library research (literature or documentation review) and observation (Wibisino, 2013:135). Documentation review is done by reading relevant literatures. Documentation can also be defined as the record of previous occurence. (Sugiyono, 2012:240)

\section{RESULT AND DISCUSSION}

\section{Company Profile}

CV. LAM ALIF is a franchise company in cooperation with Alfamart which provides everyday goods. This wholesale company (CV. LAM ALIF) is established in the early 2012, and had to experience setbacks because of low purchasing power of the targeted consumers.

\section{a. Research Result}

One of the types of sales done by the company is consignment sales, in which they sell merchant goods involving a consignor and a consignee. Consignor entrusts the products to the consignee and gives monthly $1.25 \%$ commission and $1.1 \%$ shipping fee, reduced from the cost of goods sold. 
Gross profit is calculated as the difference between net profits and cost of goods sold, while $1.1 \%$ of the deduced from the tagged price. These relationships result in the greater the income from consignment sales, the higher the gross profits, and vice versa.

Only some of the above articles are analysed in the research because not every product of CV. Lam Alif is sold using consignment method. The following are some of them sold using consignment method:

\section{Quarter 1}

From January to March in the first quarter, 306 Dji Sam Soe units are sold. According to the calculation, then the journal agreed by the consignee and consignor is carried out separately from regular sales using physical method.

The result above indicates the good performance of the company (CV. LAM ALIF) in selling Dji Sam Soe in the first quarterof 2014, exceeding the demand of the consignor stating they must sell 300 units within 90 days. The higher the sales rate, the greater commission and profits earned.

\section{Quarter 2}

From April to June in the second quarter, 349 Dji Sam Soe products are sold.

Income received by consignor

$=(\underline{\text { Rp. } 4.109 .443)}$

Profits received by consignee

$=$ Rp. 776.557

According to the above calculation then the journal agreed by consignee and consignor is carried out separately from the regular sales using physical method.

The result of the calculation reflects the performance of CV. LAM ALIF in selling Dji Sam Soe in the second quarter of 2014, as they succeed exceeding the target set by the consignor, which demands 300 units sold within 90 days. The higher the sales rate, the greater commission and profits earned.

\section{Quarter 3}

From July to September in the third quarter, 318 Dji Sam Soe products are sold.

Income received by consignor

$$
=(\underline{\text { Rp. 3.744.420) }}
$$

Profits received by consignee = Rp. 707.580

According to the above calculation then the journal agreed by consignee and consignor is carried out separately from the regular sales using physical method.

The result of the calculation reflects the performance of CV. LAM ALIF in selling Dji Sam Soe in the third quarter of 2014, as they succeed exceeding the target set by the 
consignor, which demands 300 units sold within 90 days. The higher the sales rate, the greater commission and profits earned.

\section{Quarter 4}

From October to December in the fourth quarter, 363 Dji Sam Soe products are sold.

Income received by consignor

$$
=(\underline{\text { Rp. } 4.274 .291)}
$$

Profits received by consignee

$$
=\text { Rp. } 807.709
$$

According to the above calculation then the journal agreed by consignee and consignor is carried out separately from the regular sales using physical method.

The result of the calculation reflects the performance of CV. LAM ALIF in selling Dji Sam Soe in the fourth quarter of 2014, as they succeed exceeding the target set by the consignor, which demands 300 units sold within 90 days. The higher the sales rate, the greater commission and profits earned.

\section{Quarter 1}

From January to March in the first quarter, 199 Dji Sam Soe Magnum Blue units are sold.

Income received by consignor

$$
=(\underline{\text { Rp. } 2.309 .172)}
$$

Profits received by consignee

$$
=\text { Rp. } 257.928
$$

According to the calculation, then the journal agreed by the consignee and consignor is carried out separately from regular sales using physical method. The result above indicates the inadequate performance of the company (CV. LAM ALIF) in selling Dji Sam Soe Magnum Blue in the first quarter of 2014, as the demand of the consignor stating they must sell 220 units within 90 days. The lower the sales rate, the less commission and profits earned.

\section{Quarter 2}

From April to June in the second quarter, 248 Dji Sam Soe Magnum Blue units are sold.

Income received by consignor

$$
=(\underline{\text { Rp. } 2.877 .762)}
$$

Profits received by consignee $\quad=\mathrm{Rp} . \quad 321.438$

According to the above calculation then the journal agreed by consignee and consignor is carried out separately from the regular sales using physical method. The result of the calculation reflects the great performance of CV. LAM ALIF in selling Dji Sam Soe 
Magnum Blue in the second quarter of 2014, as they succeed exceeding the target set by the consignor, which demands 220 units sold within 90 days. The higher the sales rate, the greater commission and profits earned.

\section{Quarter 3}

From July to September in the third quarter, 191 Dji Sam Soe Magnum Blue units are sold.

Income received by consignor

$$
=(\underline{\text { Rp. } 2.216 .340)}
$$

Profits received by consignee

$=$ Rp. $\quad 247.560$

According to the calculation, then the journal agreed by the consignee and consignor is carried out separately from regular sales using physical method. The result above indicates the inadequate performance of the company (CV. LAM ALIF) in selling Dji Sam Soe Magnum Blue in the third quarter of 2014, as the demand of the consignor stating they must sell 220 units within 90 days. The lower the sales rate, the less commission and profits earned.

\section{Quarter 4}

From October to November in the fourth quarter, 236 Dji Sam Soe Magnum Blue units are sold.

Income received by consignor

$$
=(\underline{\text { Rp. } 2.738 .516)}
$$

Profits received by consignee = Rp. 305.884

According to the above calculation then the journal agreed by consignee and consignor is carried out separately from the regular sales using physical method. The result of the calculation reflects the great performance of CV. LAM ALIF in selling Dji Sam Soe Magnum Blue in the fourth quarter of 2014, as they succeed exceeding the target set by the consignor, which demands 220 units sold within 90 days. The higher the sales rate, the greater commission and profits earned.

\section{LAM ALIF}

\section{Report of Profit and Loss Account}

\section{Dji Sam Soe Magnum Blue}

Sales

$$
=\text { Rp. } 11.274 .600
$$

Tagged price

$$
=\text { Rp. 10.037.016 }
$$

Commission : 15\% x Rp. 10.037.016

$=($ Rp. 1.505.552) 
Shipping fee $: 13.2 \%$ x Rp. 10.037.016 $=($ Rp. 1.324.886)

Money transferred to consignor

$$
=(\text { Rp. 7.206.578) }
$$

Profits received by consignee

$$
\text { = Rp. } 4.068 .022
$$

Profits $=$ consignment income + commission

$$
\begin{aligned}
& =\text { Rp. } 4.068 .022+\text { Rp. } 1.505 .552 \\
& =\text { Rp. } 5.573 .574
\end{aligned}
$$

\subsection{Discussion of the Research Results}

This sub-chapter discusses the valuation of the consignment sales. The data obtained based on the consignment sales include tagged price, commission, and profits for 2014, which are explained below:

Table 4.32

\section{Income from Consignment Sales in 2014}

\begin{tabular}{|c|l|c|c|cr|}
\hline \multirow{2}{*}{ No } & \multicolumn{1}{|c|}{ Products } & Tagged price & Commission & \multicolumn{2}{c|}{ Profits } \\
\hline 1 & Dji Sam Soe & Rp. 16.924.448 & Rp. 2.538.667 & Rp. 6.552 .246 \\
\hline 2 & Dji sam soe magnum blue & Rp. 10.037.016 & Rp. 1.505.552 & Rp. 4.068 .022 \\
\hline 3 & Sampoerna mild [16] & Rp. 20.192.304 & Rp. 3.028.845 & Rp. 7.813.125 \\
\hline
\end{tabular}

\subsubsection{Outcome of Consignment Sales Valuation to Profits}

The analysis of consignment sales valuation as described by the above table indicates that the profits earned is resulted from the income from consignment sales plus the commission given by the consignor. It can be concluded that the bigger the number of the products sold, the greater the commission is, and this affects the overall profits.

The commission given is the $1,25 \%$ of the tagged price in a month and $15 \%$ in a year from the agreement signed by the consignor and consignee, while the cost of goods sold is determined by the consignor. Except for the tagged price, which is determined by the consignee. The amount of commission significantly affect the amount of profits.

The profit is earned by deducing the income to be transferred to the consignor, including commission and shipping fee. The number of products sold reflect the profits, despite the difference for each of the product. A product sold in high demand is Sampoerna Mild Merah [16]. 


\subsubsection{Company's Potential to Generate Profits}

Consignment sales are highly profitable for CV. LAM ALIF and it is evident in the research result that the company's potential is very good in selling the products assigned by the consignor although there is one product which does not meet the target sales. Nevertheless, the commission earned is significant for the valuation of profits.

\section{CONCLUSION}

Based on the analysis of sales consignment of CV. LAM ALIF, the researcher concludes:

1. Based on the calculation of consignment sales explained in Chapter IV, it can be concluded that the consignment sales is evidently good, indicated by the amount of commission and profits, despite it being the gross profit or have not been deduced by other costs and tax. The commission is earned from the percentage of tagged price in a year, therefore affects profits significantly.

2. The record of consignment sales is done separately from regular sales, therefore the consignee (CV. LAM ALIF) opens a bank account to keep track on the consignment goods. This account will be debited for any cost incurred by the consignor and will be debited for the cost of goods sold. The balance is the credit for consignor and the credit balance is the debt to consignor. The account contains the obligations and rights of the consignee and consignor.

3. Consignment sales is highly profitable for CV. LAM ALIF, as the performance of the company in selling the goods is considerably good despite one product is sold below the target sales. Nevertheless, the profits are evidently great in the final calculation of revenue.

\section{REFERENCES}

Harahap, Sofyan Syafri. 2003. “Terori Akuntansi”. PT Raja Grafindo Persada, Jakarta

Rita Eni Purwanti, Indah Nugraheni. 2001. “Siklus Akuntansi”. Penerbit Kanisius.

Yogyakarta.

Baridwan, Zaki. 2004. “Intermediate Accounting”. Edisi Kedelapan. BPFE, Yogyakarta.

Belkaoui, Ahmad Riahi, dialih bahasakan oleh Marwata Dkk. 2001. “Teori Akuntansi”. Buku

Dua. Salemba Empat, Jakarta. 
Harmanto, 2002. “Akuntansi keuanngan Menengah”. Cetakan Pertama. Buku Satu, BPFE, Yogyakarta

Ikatan Akuntansi Indonesia, Revisi 2007, “Standart Akuntansi Keuangan (SAK)”. Jakarta.

Kieso, Donald E, Jerry J. Weygant, and Terry D. Warfield. 2001, “Intermediate

Accounting”. New York; John Wiley and Sons. Inc.

Warren, Carl S, James M. Reeve, and Philip E, 2005. Accounting. Ohio; South - Western

College Publishing.

Maria, Evi. 2011. “Akuntansi Lanjutan”, Cetakan Pertama. Penerbit Gava Media, Yogyakarta Arikunto, Suharsimi. 2013 “Prosedur Penelitian”, PT. Rineka Cipta, Jakarta

Halim, Abdul. 2015 “Akuntansi Keuangan Lanjutan” Mitra Wacana Media, Jakarta

Rudianto. 2009 “Pengantar Akuntansi”, Erlangga, Jakarta 